Jnl. Soc. Pol. (2022), 1-19 C The Author(s), 2022. Published by Cambridge University Press. This is an Open Access article, distributed under the terms of the Creative Commons Attribution licence (https:// creativecommons.org/licenses/by/4.0/), which permits unrestricted re-use, distribution, and reproduction in any medium, provided the original work is properly cited. doi:10.1017/S0047279421000994

\title{
Welfare Sanctions and Deprivation in Germany: Do First Sanctions Lead to Higher Levels of Deprivation Among the Long-Term Unemployed and Recipients of Basic Income Support?
}

\author{
PAUL SEVERIN LÖWE* (1) AND STEFANIE ALEXANDRA UNGER** \\ *University of Bamberg, Germany; Chair of Sociology, especially Methods of Empirical \\ Social Research; Feldkirchenstraße 21, 96052 Bamberg, Germany \\ email: paul.loewe@uni-bamberg.de \\ ** Stefanie Alexandra Unger, Institute for Employment Research; Regensburger Strasse \\ 104, 90478 Nuremberg, Germany \\ email: stefanie.alexandra.unger@gmail.com
}

\begin{abstract}
In Germany, as in many other European countries, vast changes in the welfare regime towards workfare - have taken place. As a central activating element of workfare, sanctions were introduced to take effect by temporarily increasing deprivation through benefit cuts. This paper provides first quantitative insights on the effect of first sanctions on deprivation and contributes to the recent debate on the (un)constitutionality of sanctions, which re-emerged after a verdict of the Federal Constitutional Court, criticizing the lack of knowledge about the effects of sanctions on those affected. We implement a difference-in-differences propensity score matching approach that addresses selection on observables and individual time constant unobserved differences. High data accuracy is ensured by combining the "Panel Labour Market and Social Security" (PASS) with administrative data from the Federal Employment Agency. The results illustrate a slightly higher yet statistically insignificant level of deprivation for first-sanctioned unemployment/basic income recipients compared to nonsanctioned recipients. The results hint in the direction that higher levels of deprivation are not what activates the sanctioned beneficiaries to reintegrate into the labour market. We discuss whether the results imply a significant deviation from the socio-cultural subsistence minimum of sanctioned recipients and a failure of the welfare state.
\end{abstract}

Keywords: Sanction; Deprivation; Poverty; Welfare State; Active Labour Market Policies; Difference-in-differences Propsensity Score Matching

\section{Introduction}

An ongoing question in social stratification research is whether and to what extent welfare regimes can protect unemployed people from poverty (Gallie and Paugam, 2000). Some have criticized the objective of reducing poverty through 
transfers and held generous social benefits responsible for the increasing share of the labour force who refuses labour market participation (OECD, 1999). The view of social benefits as rights, given by citizenship, shifted towards a view of social benefits as conditional on the fulfilment of obligations (Handler, 2003). Although the idea of welfare conditionality and its underlying understanding of unemployment as a lack of motivation has been criticized (Larsen and Caswell, 2020), it became dominant in many European countries that implemented stricter conditions for the receipt of benefits (Clasen and Clegg, 2007). A realignment from welfare to workfare has taken place (Bonoli, 2010).

Germany is an example of this change, as seen in its unemployment regime (Eichhorst et al., 2010). Some describe the change in Germany as so fundamental that it represents "The End of Social Security as we know it" (Bothfeld and Rosentahl, 2018). The transfers became conditional on cooperation in terms of job search and on the acceptance of job offers. Sanctions are a core element implemented to activate those long-term unemployed and other basic income recipients (Knotz, 2019). Activation with the objective of motivating recipients to (re-)integrate into the labour market is supposed to work by temporarily raising the level of deprivation. The possible increase in deprivation following the implementation of a sanction has been the subject of intense debate in Germany. Is the temporary reduction below the basic income rate caused by sanctions acceptable or does it undermine the maintenance of the socioeconomic subsistence level? In 2019, the Federal Constitutional Court declared the sanctions partly unconstitutional because of their disproportionate effect. A central point of criticism was the lack of knowledge about the effects of the sanctions on those affected (Bundesverfassungsgericht, 2019). In this paper, we shed light on the question: do first sanctions increase deprivation of long-term unemployed and basic income recipients?

Long-term unemployed and basic income recipients should be highly deprived compared to recipients of unemployment insurance benefits. A condition for receiving basic income is the inability to support oneself. Hence, we assume that most basic income recipients do not have appropriate resources to buffer benefit cuts. As a result, their level of deprivation should increase immediately even after a first sanction. However currently we do not know how the implementation of first sanctions affects the standard of living of the group of recipients of basic security benefits (Unemployment Benefits II (UB II)), who are particular vulnerable to poverty. For the UK, the consequences of more intensive use of food banks (Loopstra et al., 2018) and the emergence of a large group of people who, despite continuing to be in need, stop claiming benefits and slip into (intensified) poverty have been highlighted (Adler, 2018). For Germany, qualitative studies have found that sanctions have a very negative impact on personal situation and standard of living (Ames, 2009; Goetz et al., 2010). However, there are only insufficient quantitative results available. 
A longitudinal, quantitative investigation of the effect of sanctions on social exclusion has been performed by Grüttner et al. (2016), who do not find any significant effect of sanctions. Social exclusion is only one dimension related to poverty, and it is still unclear how first sanctions affect the standard of living as it can be measured by general deprivation.

The current study addresses this gap and contributes to the literature with an analysis of deprivation using a causal framework. Deprivation is used as a measure of poverty (Halleröd, 1995; Nolan and Whelan, 1996). This direct measurement of poverty using the Panel Labour Market and Social Security (PASS) makes it possible to identify the consequences of the first sanctions in a low-income environment, taking into account even small differences in highly disadvantaged groups whose income depends largely on social legislation and varies only due to the number of household members and some special needs. We analyse what the recipients (can) consume based on their resources, using a list of goods and activities that reflect an adequate standard of living in Germany. Compared to resource-based income measures, this has the advantage that it directly reflects the standard of living actually achieved. The combination with the administrative data of the Federal Employment Agency allows for an exact measurement of the first sanction and eliminates the problem of misreporting.

Using longitudinal data from PASS 2006-2017, we combine the strengths of two approaches (Heckman et al., 1997). Propensity score matching (PSM) eliminates observable pre-sanction differences in deprivation between sanctioned and non-sanctioned basic income recipients, measured in the data by comparing sanctioned persons to those who are similar in terms of characteristics that influence the likelihood of being sanctioned. The difference-in-differences (DiD) estimator additionally removes unobserved (not directly measured in the data) time constant differences as well as common period and ageing effects by comparing the trends of the treatment and control groups.

\section{Theoretical Framework}

The theoretical section includes a description of sanctions, deprivation and their interrelations, particularly how sanctions affect deprivation. ${ }^{1}$

\section{Sanctions}

This paper focuses on first sanctions against the recipients of basic income support (UB II), which is intended to secure the sociocultural subsistence minimum and only includes persons who have never worked ${ }^{2}$ or are long-term unemployed. ${ }^{3}$

Basic income support is a household-related benefit. The amount of the benefit depends on the number of persons living in the household and the labour market status of all household members. The benefit consists of a standard benefit 
and benefits paid for accommodation and heating, unrelated to possible former income. The individual standard benefit rate was $345 €$ in 2006 and increased to $409 €$ in 2017 (Bundesagentur für Arbeit, 2020a). Sanctions are person-related. Benefit recipients who violate their duties against the employment agency can be sanctioned; other household members are not sanctioned. The level and duration of sanctions varies. In most cases, between $10 \%$ and $30 \%$ of the proportional standard benefits are cut. The vast majority of sanctions (over $70 \%$ ) result in a benefit cut of $10 \%{ }^{4}$ (Bundesagentur für Arbeit, 2020b). Whether a $10 \%$ or $30 \%$ sanction is imposed depends on the reason for the sanction. ${ }^{5}$ Higher sanctions up to $100 \%$ of standard benefits are possible depending on age and number of sanctions during a one-year period. The average benefit reduction after a sanction (repeated sanctions included) in the years 2007-2019 was $22 \%$ of the benefit entitlement, which corresponds to an average reduction of $115 €$ (Bundesagentur für Arbeit, 202ob). Sanctions last for three months. Only for recipients under the age of 25 can sanctions be restricted to a six-week period after a case-by-case examination. ${ }^{6}$ This article focuses on the first sanctions, so the amount of benefit cuts is lower compared to the statistics cited. ${ }^{7}$

\section{Deprivation}

The measurement of poverty based on deprivation allows a comprehensive analysis of the consequences of sanctions in a low-income environment. The concept of deprivation is closely related to the definition of poverty according to the European Council (1985): "the poor shall be taken to mean persons, families and groups of persons whose resources (material, cultural and social) are so limited as to exclude them from the minimum acceptable way of life in the Member State in which they live." What is crucial is how people live and how their resources are used to secure their standard of living, not how many resources are available (Ringen, 1988; Townsend, 1987). Deprivation is measured at the household level, as the standard of living depends largely on the household context. Furthermore, we identify the truly poor by only considering goods or activities that are missing because of financial restrictions, as is the norm in deprivation research (Nolan and Whelan, 1996). The combination of financial resources and deprivation accommodates the fact that a lack of a good or service is not necessarily connected to poverty but can be a result of consumer preferences (Halleröd, 1995; Whelan et al., 2014). For example, a car can be missing because of a lack of financial resources to buy and maintain it or because the consumer prefers other means of mobility. One central criticism regarding the deprivation approach with the consideration of financial restrictions is that the consumer needs to be able to distinguish between what they cannot afford and what they do not want. The preferences need to be independent of the economic circumstances and the choice of the reference group. Empirical results indicate that this does not hold and that persons with limited 
access to resources adapt to their circumstances and adjust their preferences (Halleröd, 2006). Consequently, a conflict exists between the overestimation of deprivation (due to consumer preferences) and the underestimation of deprivation (due to an adaption of consumer preferences). Considering that both our treatment (sanctioned) and control group (non-sanctioned) basic income support recipients already belong to a low-income environment, adaption processes due to changing circumstances and reference groups are likely to be small. Therefore, to reflect varying consumer preferences, deprivation is only considered to exist if a good is missing due to financial restrictions.

\section{The connection between sanctions and deprivation}

Although the measurement of sanctions is at the individual level, and the measurement of deprivation is at the household level, this is not a central problem in determining the effect. Deprivation is measured at the household level because the standard of living depends on common goods such as a bathroom or a washing machine. However, the deprivation index is also sensitive to goods that each household member needs for himself. For example, whether each household member can afford one warm meal a day. If a member cannot afford a good, the household is considered deprived of that item. This ensures that the deprivation measurement remains sensitive to behavioural adjustments of other household members, reducing personal consumption even if the sanctioned person maintains their consumption.

We focus on unemployed people who receive basic income support, live in a community of need and have been unemployed for more than a year or have not worked long enough to qualify for unemployment benefits. The members of the community of need (usually identical to the household) form a financial community. They only receive basic income support if the members of the community cannot support themselves collectively. All members of the community of need are obliged to use up their savings (sparing only the legal allowance of usually between 3,100 Euro to 10,050 Euro - the allowance depends on and rises with the age of the individual) before receiving benefits is justified (Bundesagentur für Arbeit, 2020a). Consequently, the possibility of other household members to cushion deprivation is usually limited.

The first sanction is considered to be a temporary increase in economic precariousness caused by diminished individual transfer income, which increases the level of deprivation in the short term. This increased deprivation should enhance the cooperation of recipients and motivate them to intensify their efforts to (re-)integrate into the labour market. Both indirect (income) and direct (deprivation) poverty measures assume that a low standard of living is caused by a lack of economic resources (Halleröd, 1995). Therefore, the core of the connection between sanctions and deprivation is straightforward. The sanctioned persons have less money and can afford less, leading to rising levels 
of deprivation. We expect first sanctions to cause a higher level of deprivation for the group of first-time sanctioned basic income support recipients in comparison to recipients without a sanction.

\section{Data and Methods \\ Data}

Our data are drawn from the annually conducted German Panel Study Labour Market and Social Security (PASS) 2006-2017, waves 1-12 (Trappmann et al., 2013), and are combined with process data from the German Employment Agency (LSTS). The PASS is a household panel with a focus on low-income households, surveying approx. 5000 households who receive UBII (basic income support) every year and approximately the same amount of household from a general population sample (Berg et al., 2019). The usage of both data sets combines the advantages of very precise administrative records with rich background variables from survey data. PASS is a unique data source designed for research on the dynamics of welfare state benefit receipt and poverty. It collects detailed, longitudinal data on employment history, employability and personal contexts that are relevant for selection into sanctions, while oversampling our target group and providing detailed information on deprivation. This predisposes the dataset for analyses about poverty in a lowincome environment. We combine the PASS with administrative data on sanctions to overcome the misreporting of welfare sanctions that is likely in survey data. Respondents tend to underreport sanctions and have trouble recalling the reasons for benefit cuts. The accuracy of administrative data generated by employment agency case managers is very high because the information used is key information in the administrative process of determining the payments for UBII recipients. The sanction can be attributed to the individual who incurred it, and the information is available for all twelve waves under investigation. Overall, our data consist of 7662 control (basic income support recipients) and 289 treatment cases (basic income support recipients who receive a first sanction).

\section{Method}

To ensure that differences in the level of deprivation are really caused by the imposition of sanctions and not by other systematic differences between the group of sanctioned and the group of non-sanctioned basic income recipients, we estimate Difference-in-Differences (DiD) - Propensity Score Matching (PSM) models to reduce confounding.

PSM is used to ensure that the observed differences between the groups of sanctioned and non-sanctioned basic income recipients truly reflect a consequence of the sanction process and do not merely indicate differences in pre-sanction deprivation between the groups. This is achieved by constructing 
"statistical twins", which reduces selection effects between the two groups and makes sure that more similar sanctioned and non-sanctioned basic income recipients are compared. In PSM every individual in the treatment group (sanctioned basic income recipients) is matched with the most similar individuals in the control group (non-sanctioned basic income recipients). In a first step, we calculate one propensity score for each individual using a logistic regression based on a set of observable individual and household-level characteristics (for all variables used, see the section on Measures) that determine the likelihood of transition into a sanction. In the second step, algorithms use the information included in the propensity score to form "statistical twins" that have similar propensity scores. We choose the kernel algorithm because it performs best in our use case; it performs matching, by placing higher weight on persons close in terms of the propensity score of a treated individual and lower weight on more distant observations, to reflect the level of similarity. Third, the effect of a sanction on deprivation then is simply calculated by the weighted mean difference of the deprivation level between non-sanctioned and sanctioned basic income recipients. To test if the construction of "statistical twins" worked, we use t-tests and mean standardized biases (Table 2 of the appendix). After the implementation of PSM treatment and control group should be similar. Consequently, the t-tests should not indicate significant differences between sanctioned and non-sanctioned recipients and the mean standardized bias should be below the boundary value of $5 \%$. We were able to reduce the mean standardized bias to a level of $2.1 \%$ and all t-tests show no significant differences after matching. ${ }^{8}$

However, even in a detailed data set like PASS which is combined with administrative data not all potential confounding variables are measured and PSM can only account for observed confounders. To account also for unobserved time-constant individual differences we combine PSM with DiD. The idea of DiD is quite simple. We compare the level of deprivation before and after the imposition of a sanction in the treatment and control group. The effect of sanctioning is identified by comparing the change in deprivation of the treatment group before $\left(\mathrm{t}_{\mathrm{o}}\right)$ and after the sanction $\left(t_{1}\right)$, with the change of the control group for the same time period, to illustrate how deprivation would have developed if no treatment had taken place. A strength of the DiD-estimator is that it eliminates unobserved individual differences. An advantage, compared to a simple fixed-effects estimator, is that the betweencomparison with the trend of a control group additionally removes any common period effect that affects the treatment and control group in identical ways; any ageing effects are also removed.

Two crucial assumptions need to be fulfilled for an unbiased DIDestimator. First, the assumption of a common trend means that the trend in deprivation in the treatment and control groups would have been identical if the treatment had not taken place. The use of PSM makes the assumption of a common trend more plausible by generating two similar groups before 


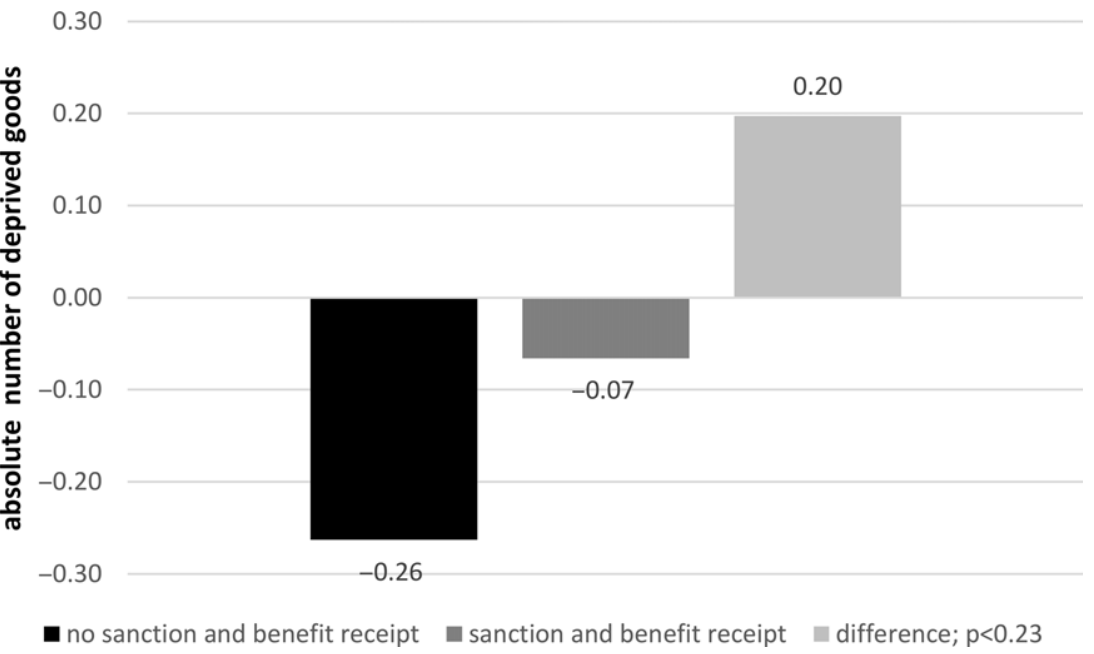

FIGURE 1. The number of deprived goods for non-sanctioned and sanctioned benefit recipients; DiD-PSM estimator from to $t_{0} t_{+1}$

Source: PASS and process data from the German Employment Agency 2006-2017, own calculations; Notes: bootstrapped standard errors, 100 replications, N (controls) $=7662$, $\mathrm{N}($ treated $)=289$

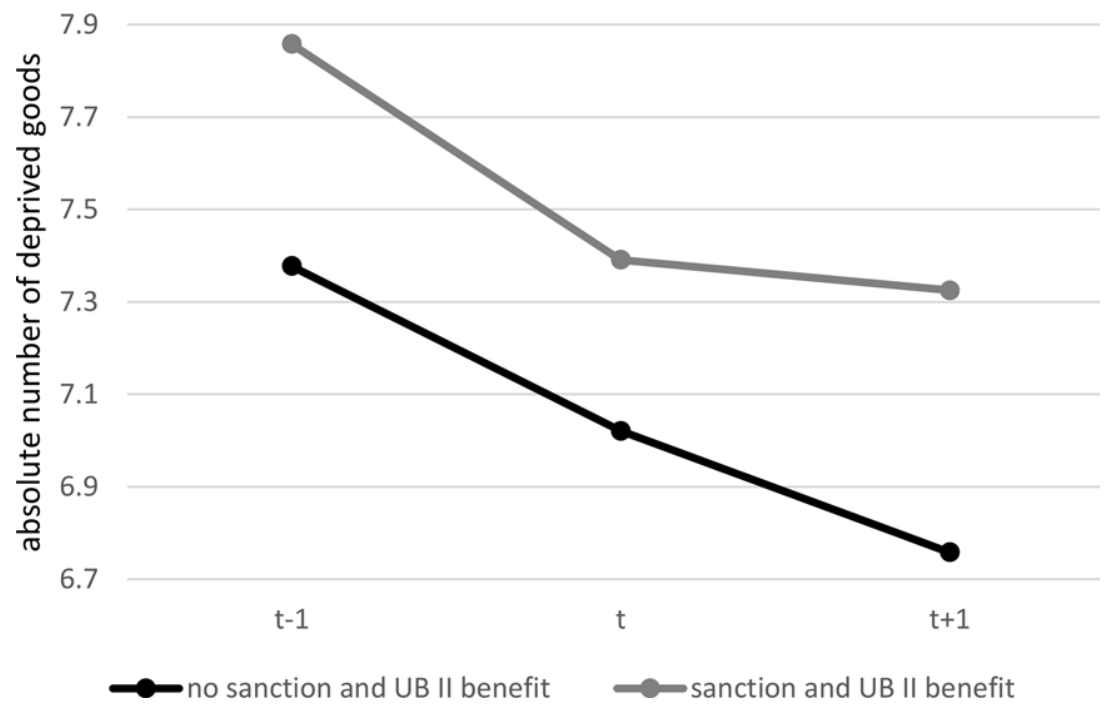

FIGURE 2 The number of deprived goods for non-sanctioned and sanctioned benefit recipients at $\mathrm{t}_{-1}, \mathrm{t}_{\mathrm{o}}$ and $\mathrm{t}_{+1}$

Source: PASS and process data from the German Employment Agency 2006-2017, own calculations; Notes: bootstrapped standard errors, 100 replications; N (controls) $=7662$, $\mathrm{N}($ treated $)=289$ 
conducting the DiD. To test the common trend, we investigate the trend before the imposition of the sanction for the matched sample and show that the assumption is fulfilled (see Figure 2, compare the trend between $t_{-1}$ and $\left.t_{o}\right) .9,10$ The second key assumption is Stable Unit Treatment Value Assumption (SUTVA) which states that the observation on one unit should be unaffected by the particular assignment of treatments to the other units. Since we use a random sample of independent households, we do not expect the sanction of a person in a household to affect the deprivation of untreated households. In the appendix, we present a detailed description of the DiDPSM estimator.

\section{Measures}

The use of the DiD-PSM estimator allows for effective reduction of confounding but requires a thoughtful consideration of times of measurement for different type of variables. For the independent variable 'first sanction', this means that we consider a benefit recipient as sanctioned if a sanction has been effective at some time during the last three months before the interview. We have chosen the three-month time window to ensure that a change in deprivation can be attributed to the sanction. For the control group, only individuals who are basic income recipients but never received a sanction are considered. To ensure that only cases from identical time points are compared, we implemented an exact matching for the wave. The information about the first sanction is taken from the process data of the employment agency, which is measured on a daily basis and reports whether a sanction for the benefit recipients was implemented due to the reasons discussed in the theoretical section. Only the first sanction of any individual can be part of our analyses. Further differentiation according to higher benefit cuts and repeated sanctions presented in a comparative perspective is not possible due to the limited number of cases. We calculate an average effect over all levels of the observed first sanctions. Consequently, we cannot say anything about whether different types of violations or repeated sanctions, causing higher level of benefit cuts or summing up to a longer period of reduced benefits, have a varying effect on deprivation. Compared to the case where all sanctions are analysed, we observe relatively low levels of benefit cuts as multiple sanctions go along with higher sanction amounts. Nevertheless, we want to emphasize that focusing on first sanctions without further differentiation provides valuable results, as the range of benefit reductions after the imposition of a sanction is narrow: $70 \%$ of all sanctions have a volume of $10 \%{ }^{11}$ of a fixed standard rate and the reduction applies to almost all recipients ${ }^{12}$ for three months (Bundesagentur für Arbeit, 2020b). So even if repeated sanctions were taken into account, the vast majority of all benefit cuts would be at the $10 \%$ level.

The dependent variable deprivation is measured at three time points. To illustrate the common trend assumption at $\mathrm{t}_{-1}$ and to calculate the DiD- 
estimator at $t_{o}$ (wave before the imposition of a sanction) and $t_{+1}$ (wave after the sanction). Deprivation is measured with an index, taken from the PASS and is measured on the household level. The deprivation index includes 23 goods from the dimensions of habitation, food/clothing, consumption, finance and social participation. ${ }^{13}$ We use the full index because we are interested in the first sanction's effect on the overall standard of living. Most of the 23 items used to measure deprivation are identical to other European studies (Nolan and Whelan, 1996; Halleröd, 1995). Selective deviations in the operationalization of deprivation can occur because the index depicts goods and activities that are considered particularly important in German society with regard to an adequate standard of living (Beste et al., 2014). Furthermore, it has been shown that deprivation measures are relatively insensitive to deviations in the lists of items used for data collection (Andreß and Lipsmeier, 2001). A good is included in the deprivation index if it is not available for at least one household member for financial reasons. The following example (HLSo10o-HLS130ob) illustrates the measurement.

"If you think of your household, which of the following items do you have?

Do you have sufficient winter clothing [for each household member]?

1. [We] have that

2. [We] don't have that

$[\ldots]$

If not mentioned: And why don't you have that? For financial reasons or for other reasons?

1. [We] don't have that for financial reasons

2. [We] don't have that for other reasons"

We use a simple sum index built from these 23 items, as this hardly deviates from the weighted indices, but its construction is more intuitive and more illustrative (Andreß et al., 2004). It is to be expected that some goods in the index react more sensitively to the first sanction, as they are consumed more frequently and are more directly affected by even small changes in disposable income. This is not a problem as it does not affect the accuracy of the index if not all goods react equally sensitively to a first sanction. The goods included in the index are presented in Table 3 in the appendix.

The third group of variables are control variables, used to calculate the propensity score. All control variables are measured before the imposition of the treatment for two reasons. First, to reduce endogeneity problems (especially reverse causality) the covariates that determine selection into treatment should 
not be consequence of the treatment. The covariates must be measured before the treatment (sanction), and the treatment must be measured before the outcome (deprivation). Second, we need to test the common trend assumption on the basis of the matched sample to ensure that the number of cases is constant, and the common trend assumption is fulfilled for the sample used for the calculation of the DiD-PSM-estimator.

For our matching model, we use an extensive set of control variables at the individual, household and structural levels. To control for potential buffering effects, support opportunities and varying legal claims regarding the first sanction, the recipient's household's social and financial context is measured (savings and debts). We also match the size of the household (Achatz and Trappmann, 2011; Kalil et al., 2002; Hasenfeld et al., 2004) or whether young children ( $\$ 10$ Abs. 1, Nr.3 SGB II) live in the household, whether a partner is present in the household, if he/she is a single parent (Lietzmann et al., 2011), the number of close friends (Ames, 2009; Andreß, 1999), debts and savings and the duration of the basic income support receipt (Dahl and Lorentzen, 2003; Hirseland and Lobato, 2010; Behrend and Ludwig-Mayerhofer, 2008). Mental health status and visits to doctors ( $\$ 10$ Abs.1 Nr.1 SGB II, Behrend and Ludwig-Mayerhofer, 2008; Schreyer and Götz, 2010) are included to control for the ability to work, which influences how strictly recipients are activated. Furthermore, the income potential before the receipt and productivity differences are considered according to the level of school and professional education (Gschwind, 2013; Ludwig-Mayerhofer and Sondermann, 2012). The sociodemographics - i.e. sex (Wolff and Moczall, 2012), age (\$31a Abs.2 SGB II; Behrend and Ludwig-Mayerhofer, 2008; Kumpmann, 2009; Schreyer et al., 2013) and migration background (Wolff and Moczall, 2012; Statistisches Bundesamt, 2008) - are included because they may be connected to knowledge of institutions, discrimination, former income and interaction with the employment agency. Opportunities to find a new job, receive job offers and therefore reach cooperation, local differences between employment agencies regarding sanction frequencies, and income potential are approximated by the regional unemployment rate (county level; Boockmann et al., 2009; Müller and Oschmiansky, 2006; Schneider, 2007).

\section{Results}

We expected a higher level of deprivation for the treatment group of first-sanctioned persons. Indeed, the DiD-PSM estimator shows that the deprivation level has increased by an average of 0.20 goods for treatment compared to the control group (Figure 1 and Figure 2). The results indicate a slight increase in deprivation after the imposition of a first sanction. Statistically, the effect is insignificant $(\mathrm{p}<0.23)$. 
Figure 2 and Figure 1 in the appendix show that the level of deprivation is high and that the standard of living is low for all basic income recipients. Figure 2 presents the absolute, Figure 1 in the appendix the percentage of deprived goods for both matched groups from $t_{-1}$ to $t_{0}$ (common trend) and from $t_{\mathrm{o}}$ to $t_{+1}$ (Did-PSM estimator) and both indicate that the level of deprivation is higher for the treated group even before the treatment and that the level of deprivation diminishes for all recipients over time. The small positive effect size found in the DiD-PSM model can be attributed to a lower reduction in deprivation over time in the treated group due to the sanction. For recipients without a sanction at $t_{+1}$, an average of 6.76 goods (29.38\% of all goods) are missing, compared to 7.33 (31.85\% of all goods) in the treated group. However, the central reason for a generally high level of deprivation is the receipt of basic income support, not the imposition of first sanctions. Regarding this point, our results are in line with the work of Christoph (2008). He uses PASS data from the years 2006/ 2007 and presents results that in the general population, on average, 1.94 goods of the 23 goods of the deprivation index are missing, while for the group of basic income recipients, 7.24 goods are missing. In an index of 23 goods, this means that in both groups, over $30 \%$ of goods are missing due to financial restrictions.

We also performed further analyses to test why first sanctions do not show a huge impact on deprivation. Specifically, we analyse whether the available financial resources do or do not reduce and what differences in deprivation occur for various household compositions. The first sanction does not seem to have a huge effect on deprivation because the household income does not decrease much. We only find a slight (and insignificant; $\mathrm{p}<0.60$ ) difference of $8 €$ in the equivalence-weighted net household income between sanctioned and non-sanctioned recipients in the PASS data (Figure 2, in the appendix). The reduction in income on the household level does not seem to be large enough to have a substantial effect on deprivation. In our models, we control for household composition, but we are also looking at different household compositions separately to check if other household members are able to buffer benefits cuts. This seems to be the case. The effect of a first sanction on deprivation is higher in single ( 0.35 goods; $\mathrm{p}<0.30$ ) and single-parent households ( 0.35 goods; $\mathrm{p}<0.26$; Figure 3, in the appendix). The stronger effect in single- and single-parent households is a hint that other household members are able to buffer benefit cuts.

\section{Discussion}

This article sought to reveal the short-term effects of first sanctions on deprivation for basic income recipients and contribute to the debate on sanctions. The empirical results illustrate small positive but insignificant effects of first sanctions on deprivation. Independent of the statistical significance of the effect, 
we need to discuss whether the increase in deprivation by an average of 0.20 goods caused by first sanctions is meaningful.

We want to discuss this in relation to three points. First, if the government intends that basic income support guarantees the socio-cultural subsistence level (Goetz et al., 2010), any downward deviation that undermines this goal, at least in the short term, needs to be prevented. The guarantee of a minimum cannot be conditional on cooperation. Otherwise, the welfare state fails to maintain the socioeconomic subsistence level. In this respect, the results point in the direction of a fundamental change as diagnosed by Bothfeld and Rosentahl (2018).

Second, in relation to the level of deprivation in the general population (1.94 goods on average), an increase of 0.2 goods is relevant. The increase in the already highly deprived environment of basic income recipients seems to be small but can be seen as particularly problematic, as the already high level of deprivation is further increased.

Third, we can discuss our results against the background whether the increased level of deprivation caused by the sanction fulfils the goal to improve cooperation of the beneficiaries and gets them back to work. At least it is questionable how a deprivation of, on average, less than half a good should be the main motivator to re-establish cooperation with the employment agency. Nevertheless, positive effects of sanctions on the probability of re-employment have been found in many European countries (Arni et al., 2013; Abbring et al., 2005; Lalive et al., 2005) and also for Germany (van den Berg et al., 2019; Wolff, 2014). One possible explanation is that benefit recipients cooperate because they expect increased deprivation in case of sanctions - irrespective of whether sanctions or deprivation actually occur for themselves. The importance of such ex ante effects, created by the threat of sanctions, is emphasized in literature (Boone et al., 2009; Gurr et al., 2018). If this were the case, one could conclude that the desired effect of higher re-employment for many can be achieved with a moderate reduction in living standards for a few, which could lead to the recommendation to policy makers to use sanctions more intensively. Besides the question of whether this is morally justifiable it is also plausible that it is not the reduction in living standards that increases the probability of re-employment, but other consequences associated with the sanction that need to be taken into account when evaluating sanctions.

Negative consequences that sanctioned individuals may wish to avoid can include stigma or negative mental health impacts, as has been found in the US (Davis, 2019; Williams, 2021). However, the stigma argument does not find support in a recent German study (Gurr et al., 2018), showing that stigma consciousness is lower in the group of the sanctioned than the unsanctioned. Here, too, the importance of the ex-ante effect is emphasized, according to which the constant threat of a sanction has a stronger effect than the sanction itself. It also might be the case that the often more intense support from the case manager of the employment agency 
after a sanction may lead to better labour market opportunities. However, more intensive support could also be provided without a sanction.

Our further analyses show that a possible explanation for the relatively small and insignificant effect of first sanctions on deprivation can be found in our analysis of the effect of sanctions on the equivalence-weighted net household income. First sanctions do not decrease household income substantially. Since the sanction should lower income, which should increase deprivation, we need to look at possible explanations why the income does not decrease after a sanction. One explanation would be that the recipients adapt to their situation, and therefore reduce the effect of sanctions. For example, more intensive use of food banks following sanction has been demonstrated for the UK (Loopstra et al., 2018). The use of these civil society services in the occurrence of sanction would buffer their impact on deprivation. Some recipients report that they find new sources of income through illicit employment (Gurr et al., 2018). Another explanation is that sanctioned recipients can activate further support in their social network. Possible financial support from one's network cannot be mapped with the data. In addition, support through other household members is possible. We test whether first sanctions have a stronger impact in single households that do not have the possibility to buffer benefit cuts through other household members. The results indicate this is the case, which also means that not only the resources of the sanctioned recipient are affected, but other household members also face the consequences of the sanction in a kind of collective punishment. This would contradict the idea that only the individual recipient who does not cooperate has to bear the consequences of a reduction in benefits. A situation is created in which it is not the welfare state that supports the recipient, but the family, private relationships or civil society actors who secure the subsistence level. This can be interpreted as part of an undesirable shift of risks from the state to individuals and their networks.

Regarding the adaption processes, we found that the level of deprivation declines for all recipients (sanctioned and non-sanctioned) over time. This is also the case if not only goods that are missing for financial reasons are taken into account. Therefore, it is unlikely that only preferences change. The level of deprivation declines over time for both groups before the implementation of a sanction. The results, although not significant, indicate that this development is weakening for the group of sanctioned recipients. However, the results remain puzzling in this regard. The general decrease in deprivation for both groups might (partly) be caused by panel attrition, which is likely to be higher for respondents who are particularly prone to poverty. Another possible explanation is that standard benefit rates increased over time, from $345 €$ in 2006 to $409 €$ in 2017 (Bundesagentur für Arbeit, 2020a). It is also conceivable that recipients (regardless of a sanction) learn ways to reduce deprivation themselves and to compensate for risks formerly covered by the welfare state by using 
institutions that offer free or almost free food to the needy as well as very inexpensive used clothing and furniture.

While this paper focused on the average direct, short-term effects of first sanctions on deprivation, further research with larger samples is needed to overcome the limitations primarily imposed by available case numbers in the data and allow for finding significant effects and greater differentiation in the analyses. We calculated a composite effect of first sanctions. Repeated sanctions leading to higher benefit cuts might have a higher effect on deprivation, explaining positive effects on re-employment. In addition, possible long-term effects and age group differences should be investigated. It is possible that deprivation levels among recipients under the age of 25 are affected by sanctions, but this does not show up in the composite effect. There is a need for research here, as some qualitative studies argue that, for example, young benefit recipients are strongly affected by sanctions (Schreyer et al., 2013). It would be beneficial to investigate how different volumes of benefit cuts and multiple sanctions over a longer time affect deprivation. In addition, possible explanations, such as those raised in the discussion as to why sanctions do not lead to lower household incomes and stronger deprivation effects, must be tested with appropriate data. Furthermore, a detailed analysis is needed to determine the exact reasons why the sanctioned group returns to the labour market faster than similar non-sanctioned recipients.

\section{Acknowledgements}

The author thanks Jonas Voßemer, Michael Gebel, Mark Trappmann and the anonymous reviewers for their insightful comments, suggestions and support. We also thank the discussants and participants at the 2016 Summer Meeting "Economic inequalities, deprivation, and poverty" of the Research Committee 28 on Social Stratification and Mobility (RC28) at the University of Bern, Switzerland and discussants and participants at the 2017 ECSR Conference "Institutions, inequalities and social dynamics" at the Bocconi University Milan, Italy.

\section{Competing interests}

The authors declare none.

\section{Supplementary material}

To view supplementary material for this article, please visit https://doi.org/10. $1017 /$ So047279421000994

\section{Notes}

1 For a detailed description of legal issues regarding sanctions for the long-term unemployed in Germany, see Wolff and Moczall (2012).

2 They have never worked before but are classified as employable. 
3 In most cases, this means unemployment lasting longer than one year. Depending on age, this can be expanded up to two years.

4 Before March 2011 the repeated omission of report resulted in a $20 \%$ reduction of the standard benefit rate.

5 For the different amounts of benefits according to the composition of the household and reasons for $10 \%, 30 \%$ and higher cut-offs for the first sanction, see Table 1 in the appendix.

6 Although the possibility to limit the duration of a sanction to six weeks is limited to benefit recipients under 25 years of age, the average benefit reduction is higher for this group, as higher benefit reductions are already applied for the first violations of obligations (see Table 1 in the Appendix).

7 We discuss the reasons for this restriction in the section on "Measures".

8 Although the mean standardized reduces to a level of $2.1 \%$ not every single variable meets the boundary value of a standardized bias reduction below $5 \%$. Sex, age, size of household, partner, Duration of UB II receipt do not meet the boundary value of a standardized bias reduction below $5 \%$.

9 Unfortunately, it is not possible to use more pretreatment waves to test the common trend assumption because the PASS survey data limits our case numbers. More than the $t_{-1}$ wave to test the common trend assumption is not feasible because the number of cases decreases too much. The sharp decrease in the number of cases is because sanctions have been imposed less frequently in recent years and that more successive waves need to be filled, which is problematic due to panel attrition. For example, the number of cases treated decreases from 484 to 289 if we include only the $t_{-1}$ wave, compared to the case where we only analyse the change in deprivation from directly before $\left(t_{0}\right)$ and after the treatment $\left(\mathrm{t}_{1}\right)$.

10 We test the common trend assumption on the basis of the matched sample to ensure that the number of cases is constant, and the common trend assumption is correct for the sample used later.

11 This includes repeated sanctions. Before March 2011 the repeated omission of report resulted in a $20 \%$ reduction of the standard benefit rate.

12 Only in the case of persons under 25 years of age can the sanction be optionally limited to six weeks after a case-by-case assessment $(\$ 31$ Abs. 6 SGB II, since April $2011 \S 31$ b Abs. 1 SGB II). Of course, multiple sanctions can sum up to a longer period, but each sanction itself remains for three months.

13 For a detailed description of the deprivation index used in PASS, see Berg et al. (2019).

\section{References}

Abbring, J. H., van den Berg, G. J. and van Ours, J. C. (2005), 'The Effect of Unemployment Insurance Sanctions on the Transition Rate from Unemployment to Employment', The Economic Journal, 115, 602-630.

Achatz, J. and Trappmann, M. (2011), 'Arbeitsmarktvermittelte Abgänge aus der Grundsicherung', IAB-Discussion Paper, 2, 1-41.

Adler, M. (2018), Cruel, Inhuman or Degrading Treatment? Benefit Sanctions in the UK, Basingstoke: Palgrave Macmillan.

Ames, A. (2009), Ursachen und Auswirkungen von Sanktionen nach $\$_{31}$ SGBII, Düsseldorf: Hans-Böckler-Stiftung.

Andreß, H.-J. (1999), Leben in Armut: Analysen der Verhaltensweisen armer Haushalte mit Umfragedaten, Opladen/Wiesbaden: Westdeutscher Verlag GmbH. 
Andreß, H.-J., Krüger, A. and Sedlacek, B. K. (2004), Armut und Lebensstandard Zur Entwicklung des notwendiges Lebensstandards der Bevölkerung 1996-2003: Gutachten im Rahmen des Armuts- und Reichtumsberichtes der Bundesregierung, Köln.

Andreß, H.-J. and Lipsmeier, G. (2001), 'Armut und Lebensstandard', in Bundesministerium für Arbeit und Sozialordnung (ed.), Lebenslagen in Deutschland. Der erste Armuts- und Reichtumsbericht der Bundesregierung, Bonn: BMAS.

Arni, P., Lalive, R. and van Ours, J. C. (2013), 'How Effective are Unemployment Benefit Sanctions?: Looking Beyond Unemployment Exit', Journal of Applied Econometrics, $28,7,1153-1178$.

Behrend, O. and Ludwig-Mayerhofer, W. (2008), 'Sisyphos motivieren, oder: Der Umgang von Arbeitsvermittlern mit Chancenlosigkeit', Zeitschrift für Sozialreform, 54, 1, 37-56.

Berg, M., Cramer, R., Dickmann, C., Gilberg, R., Jesske, B., Kleudgen, M., Beste, J., Dummert, S., Frodermann, C., Schwarz, S., Trappmann, M., Bähr, S., Coban, M., Friedrich, M., Gundert, S., Müller, B., Teichler, N., Unger, S. and Wenzig, C. (2019), Codebook and Documentation of the Panel Study "Labour Market and Social Security" (PASS) Datenreport Wave 12, Nürnberg: Institut für Arbeitsmarkt- und Berufsforschung.

Beste, J., Bethmann, A. and Gundert, S. (2014), 'Sozialstruktur und Lebensumstände: Materielle und soziale Lage der ALG-II-Empfänger', IAB Kurzbericht, 24, 1-8.

Bonoli, G. (2010), 'The Political Economy of Active Labor-Market Policy', Politics \& Society, $38,4,435-457$.

Boockmann, B., Thomson, S.L. and Walter, T. (2009), 'Intensifying the use of benefit sanctions: an effective tool to shorten welfare receipt and speed up transitions to employment?', ZEW Discussion Papers, 9, 72, 1-31.

Boone, J., Sadrieh, A. and van Ours, J. C. (2009), 'Experiments on unemployment benefit sanctions and job search behaviour', European Economic Review, 53, 937-951.

Bothfeld, S. and Rosentahl, P. (2018), 'The End of Social Security as we know it - The Erosion of Status Protection in German Labour Market Policy', Journal of Social Policy, 47, 2, 275-294.

Bundesagentur für Arbeit (2020a), Geldleistungen und Recht SGB II, Elsterwerda: Variograph $\mathrm{GmbH}$.

Bundesagentur für Arbeit (2020b), Grundlagen: Methodenbericht-Jährliche Sanktionsverlaufsquote, Nürnberg: Bundesagentur für Arbeit.

Bundesverfassungsgericht (2019), 'Sanktionen zur Durchsetzung von Mitwirkungspflichten bei Bezug von Arbeitslosengeld II teilweise verfassungswidrig', Pressemitteilung.

Christoph, B. (2008), 'Was fehlt bei Hartz IV?: Zum Lebensstandard der Empfänger von Leistungen nach SGB II'.

Clasen, J. and Clegg, D. (2007), 'Levels and Levers of Conditionality: Measuring Change within Welfare States', in J. Clasen and N. A. Siegel (eds.), Investigating Welfare State Change: The Dependent Variable Problem' in Comparative Analysis, Cheltenham: Edward Elgar Publishing, 166-197.

Dahl, E. and Lorentzen, T. (2003), 'Explaining Exit to Work among Social Assistance Recipients in Norway: Heterogeneity or Dependency?', European Sociological Review, $19,5,519-536$.

Davis, O. (2019), 'What is the Relationship between Benefit Conditionality and Mental Health?: Evidence from the United States on TANF Policies', Journal of Social Policy, $48,2,249-269$.

Eichhorst, W., Grienberger-Zingerle, M. and Konle-Seidl, R. (2010), 'Activating Labor Market and Social Policies in Germany: From Status Protection to Basic Income Support', German Policy Studies, 6, 1, 65-106.

European Council (1985), 'Council Decision of 19 December 1984 on specific Community action to combat poverty: 85/8/EEC', Official Journal of the European Communities, $24-25$. 
Gallie, D. and Paugam, S. (2000), 'The Experience of Unemployment: The Debate', in D. Gallie and S. Paugam (eds.), Welfare Regimes and the Experience of Unemployment in Europe, New York: Oxford University Press, 1-22.

Goetz, S., Ludwig-Mayerhofer, W. and Schreyer, F. (2010), 'Sanktionen im SGB II: Unter dem Existenzminimum', IAB-Kurzbericht, 10, 1-8.

Grüttner, M., Moczall, A. and Wolff, J. (2016), 'Sanktionen im aktivierenden Arbeitsmarktregime und soziale Exklusion: Eine quantitative Analyse', Soziale Welt, $67,1,67-90$.

Gschwind, L. (2013), The effect of education on sanction probability in the German welfare state, Konstanz.

Gurr, T., Unger, S. and Jungbauer-Gans, M. (2018), 'Gehen Sanktionen mit einem höheren Stigmabewusstsein bei Arbeitslosen einher?', Zeitschrift für Sozialreform, 64, 2, 217-248.

Halleröd, B. (1995), 'The Truly Poor: Direct and Indirect Consensual Measurement of Poverty in Sweden', Journal of European Social Policy, 5, 2, 111-129.

Halleröd, B. (2006), 'Sour Grapes: Relative Deprivation, Adaptive Preferences and the Measurement of Poverty', Journal of Social Policy, 35, 03, 371-390.

Handler, J. F. (2003), 'Social Citizenship and Workfare in the US and Western Europe: From Status to Contract', Journal of European Social Policy, 13, 3, 229-243.

Hasenfeld, Y., Ghose, T. and Larson, K. (2004), 'The Logic of Sanctioning Welfare Recipients: An Empirical Assessment', Social Service Review, 78, 2, 304-319.

Heckman, J. J., Ichimura, H. and Todd, P. E. (1997), 'Matching as an econometric evaluation estimator: evidence from evaluating a job training programme', Review of Economic Studies, 64, 4, 605-654.

Hirseland, A. and Lobato, P. R. (2010), 'Armutsdynamik und Arbeitsmarkt: Entstehung, Verfestigung und Überwindung von Hilfebedürftigkeit bei Erwerbsfähigen', IABForschungsbericht, 3, 1-41.

Kalil, A., Seefeldt, K. S. and Wang, H.-C. (2002), 'Sanctions and Material Hardship under TANF', Social Service Review, 76, 4, 642-662.

Knotz, C. (2019), 'Why Countries 'Get Tough on the Work-Shy': The Role of Adverse Economic Conditions', Journal of Social Policy, 48, 3, 615-634.

Kumpmann, I. (2009), 'Im Fokus: Sanktionen gegen Hartz-IV-Empfänger: Zielgenaue Disziplinierung oder allgemeine Drohkulisse?', Wirtschaft im Wandel, 15, 6, 236-239.

Lalive, R., Zweimüller, J. and van Ours, J. C. (2005), 'The effect of benefit sanctions on the duration of unemployment', Journal of the European Economic Association, 3, 6, $1386-1417$.

Larsen, F. and Caswell, D. (2020), 'Co-Creation in an era of Welfare Conditionality - Lessons from Denmark', Journal of Social Policy, 49, 1-19.

Lietzmann, T., Tophoven, S. and Wenzig, C. (2011), 'Grundsicherung und Einkommensarmut: Bedürftige Kinder und ihre Lebensumstände', IAB-Kurzbericht, 6, 1-12.

Loopstra, R., Fledderjohann, J., Reeves, A. and Stuckler, D. (2018), 'Impact of Welfare Benefit Sanctioning on Food Insecurity: A Dynamic Cross-Area Study of Food Bank Usage in the UK', Journal of Social Policy, 47, 3, 437-457.

Ludwig-Mayerhofer, W. and Sondermann, A. (2012), 'Fördern und Fordern ... aber wen eigentlich? Reproduktion sozialer Ungleichheit in der Arbeitsverwaltung', in M. Berswill, C. Figlestahler, Yashodhara Haller, L., Perels, M and F. und Zahradnik (eds.), Wechselverhältnisse im Wohlfahrtsstaat. Dynamiken gesellschaftlicher Justierungsprozesse, Münster: Westfälisches Dampfboot, 194-211.

Müller, K. U. and Oschmiansky, F. (2006), 'Die Sanktionspolitik der Arbeitsagenturen nach den Hartz- Reformen: Analyse der Wirkungen des Ersten Gesetztes für moderne Dienstleistungen am Arbeitsmarkt', WZB Discussion Papers, 116, 1-33.

Nolan, B. and Whelan, C. T. (1996), 'Measuring Poverty Using Income and Deprivation Indica-tors: Alternative Approaches', Journal of European Social Policy, 6, 3, 225-240.

OECD (1999), Benefit Systems and Work Incentives, Paris: OECD. 
Ringen, S. (1988), 'Direct and Indirect Measures of Poverty', Journal of Social Policy, 17, 03, 351-365.

Schneider, J. (2007), 'Sanktionen im SGBII: Wer wird sanktioniert und warum? Was wissen wir bislang über Sanktionen in Sozialsystemen', efas Newsletter, 10, 1-4.

Schreyer, F. and Götz, S. (2010), 'Sanktionen bei jungen Arbeitslosen im SGB II: Wer nicht hören will, muss fühlen', IAB Forum, 1, 80-85.

Schreyer, F., Zahradnik, F. and Götz, S. (2013), 'Sanktionen bei jungen Arbeitslosen im SGB II - Wenn das Licht ausgeht', IAB Forum, 2, 60-67.

Statistisches Bundesamt (2008), Datenreport 2008. Ein Sozialbericht für die Bundesrepublik Deutschland, Wiesbaden.

Townsend, P. (1987), 'Deprivation', Journal of Social Policy, 16, 02, 125-146.

Trappmann, M., Beste, J., Bethmann, A. and Müller, G. (2013), 'The PASS panel survey after six waves', Journal for Labour Market Research, 46, 4, 275-281.

van den Berg, G. J., Uhlendorffm, A. and Wolff, J. (2019), 'The impact of sanctions for young welfare recipients on transitions to work and wages and on dropping out', Institute for evaluation of labour market and educational policy - Working Paper, 5, 1-30.

Whelan, C. T., Nolan, B. and Matre, B. (2014), 'Multidimensional poverty measurement in Europe: An application of the adjusted headcount approach', Journal of European Social Policy, 24, 2, 183-197.

Williams, E. (2021), 'Unemployment, sanctions and mental health: The relationship between benefit sanctions and antidepressant prescribing', Journal of Social Policy, 50, 1, 1-20.

Wolff, J. (2014), 'Sanktionen im SGB II und ihre Wirkungen', IAB Stellungnahme, 2, 1-17.

Wolff, J. and Moczall, A. (2012), 'Übergänge von ALG-II-Beziehern in die erste Sanktion: Frauen werden nur selten sanktioniert', IAB-Forschungsbericht, 11, 1-74. 